Thompson, S. Y., Ganguly, J. \& Kon, S. K. (1949). Brit. F. Nutrit. 3, 50.

Verzár, F. \& McDougall, E. J. (1936). Absorption from the Intestine, p. 222. London: Longmans, Green and Co.

With, T. K. (1939). Nord. Med. 3, 2903.

Wright, J. G. (1947). Veterinary Anaesthesia, and ed., p. 139. London: Baillière, Tindall and Cox.

EXPLANATION OF PLATE

Pl. I. London's cannula, protective Perspex dome and collecting bottle.

\title{
A Demonstration of the Conversion of Carotene into Vitamin A in Conscious Rats
}

\author{
By JUNE ALEXANDER \\ Physiological Laboratory, Department of Physiology and Histology, \\ University of Liverpool \\ AND T. W. GOODWIN \\ Department of Biochemistry, University of Liverpool \\ (Received 23 Fune 1950)
}

There is now considerable evidence that in animals carotene is converted into vitamin $A$ in either the lumen or the wall of the intestine, most probably in the latter. 'This has been proved in many ways by experiments both in vivo and in vitro on a variety of animals (Glover, Goodwin \& Morton, 1947, r948; Goodwin \& Gregory, 1948; Wiese, Mehl \& Deuel, I947; Mattson, Mehl \& Deuel, 1947; Thompson, Ganguly \& Kon, 1947, 1949; Mattson, I948; Krause \& Pierce, I948; Thompson, Coates \& Kon, 1950; Lane, 1950). In particular, Goodwin \& Gregory (1948) showed that carotene, introduced into the intestine of conscious goats provided with an abomasal or duodenal fistula and a thoracic duct fistula, gave rise to increased amounts of vitamin $A$ in the lymph but no carotene.

Although the conversion in the rat's intestine has been well established, it has not been confirmed in conscious animals by the method applied to goats and since, primarily for another purpose, the intestinal lymphatics of a large number of rats were being cannulated, the opportunity was taken of using some of the animals to follow the changes in the vitamin A content of the lymph after oral administration of $\beta$-carotene. These experiments were in progress when Coates, Thompson \& Kon (I950) gave a preliminary report of the results of their extensive investigation carried out along similar lines. Our own was then discontinued, but the results obtained are briefly reported here because they completely confirm those of the Reading investigators, which are published in full in the paper just preceding this one ('Thompson, Braude, Coates, Cowie, Ganguly \& Kon, I950).

\section{EXPERIMENTAL}

Preparation of rats. The intestinal lymphatic vessel was cannulated with fine polythene tubing in an aseptic operation under ether anaesthesia by the technique devised by Bollman, Cain, Grindlay \& van Hook (1948). In their original description 
of the operation Bollman et al. show the superior mesenteric artery as lying close beside the hepatic lymphatic; it does in fact lie beside the main intestinal lymphatic, and in rats weighing less than $25^{\circ} \mathrm{g}$. it may be almost impossible to cannulate the lymphatic vessel satisfactorily; either the artery is damaged or the lymphatic vessel is torn, which leads to subsequent leakage of the lymph. In larger rats the artery lies more to one side of the lymphatic vessel and the plastic tube can readily be introduced and tied in position with a fine ligature without damaging the artery.

After recovering from the anaesthetic the rats were placed in a cage of the type described by Bollman \& van Hook (1948) and maintained in a constant-temperature cabinet at $25^{\circ}$ during the experiment. It was found desirable to leave about $25 \mathrm{~cm}$. of plastic tubing outside the animal so that when it was filled with lymph, slight suction was exerted upon the lymphatic vessels. Once flow began it usually continued without clotting for at least $\mathrm{I}-2$ days. The report (Mann, Mann \& Bollman, 1949) that haemorrhages occur in cannulated rats when lymph drainage continues for more than about $24 \mathrm{hr}$., and that the haemorrhagic tendency can be prevented by administration of vitamin $\mathrm{K}$, was confirmed.

After the operation the rats, which had previously been maintained on rat cubes supplied by Lever Bros. and Unilever Ltd., were kept without food for $24 \mathrm{hr}$. and then dosed by stomach tube with $0.5 \mathrm{ml}$. of refined arachis oil in which had been dissolved a known amount of crystalline carotene (a mixture of about $90 \% \beta$ - and $10 \%$ $\alpha$-carotene); in different experiments the amount varied from 100 to $120 \mu \mathrm{g} . / \mathrm{ml}$. arachis oil. In control experiments the rats were dosed only with arachis oil. The lymph, collected for $\mathrm{x} 8-22 \mathrm{hr}$. before dosing and for $6-8 \mathrm{hr}$. afterwards, was examined for vitamin $\mathrm{A}$ by the antimony-trichloride test in conjunction with a Beckman spectrophotometer, according to the method previously described (Goodwin \& Gregory, 1948).

\section{RESULTS}

The results (Table 1 ) clearly indicate that after $\beta$-carotene dissolved in arachis oil had been given, there was a marked rise in the concentration of vitamin $A$ in the

Table I. The effect of carotene administered orally on the vitamin $A$ content of the intestinal lymph of conscious rats

\begin{tabular}{|c|c|c|c|c|c|c|}
\hline & & & & aph & & \\
\hline & Before & ministratic & of dose & After a & ginistratior & of dose \\
\hline Dose & $\begin{array}{l}\text { Period of } \\
\text { collection } \\
\text { (hr.) }\end{array}$ & $\begin{array}{l}\text { Volume } \\
\text { collected } \\
(\mathrm{ml} .)\end{array}$ & $\begin{array}{c}\text { Vitamin A } \\
\text { (i.u./ } \\
\text { roo ml.) }\end{array}$ & $\begin{array}{l}\text { Period of } \\
\text { collection } \\
\text { (hr.) }\end{array}$ & $\begin{array}{l}\text { Volume } \\
\text { collected } \\
\text { (ml.) }\end{array}$ & $\begin{array}{c}\text { Vitamin A } \\
\text { (i.u.) } \\
\text { roo ml.) }\end{array}$ \\
\hline Arachis oil only, $0.5 \mathrm{ml}$. & I8 & $9 \cdot 6$ & 42 & 6 & 5.5 & 44 \\
\hline & 23 & $12 \cdot 4$ & 26 & 6 & $8 \cdot 9$ & 29 \\
\hline$\beta$-carotene, $50-60 \mu \mathrm{g}$. in & 22 & $9 \cdot 6$ & 26 & 5 & $7 \cdot 5$ & 68 \\
\hline $0.5 \mathrm{ml}$. arachis oil & 22 & $12 \cdot 9$ & 43 & $6 \cdot 25$ & $5 \cdot 1$ & $5 \mathrm{I}$ \\
\hline & 22 & $2 \cdot 8$ & 87 & 8 & $3 \cdot 6$ & I 21 \\
\hline & 19 & $6 \cdot 9$ & 59 & 8 & $8 \cdot 4$ & 76 \\
\hline & 22 & $5 \cdot 3$ & 34 & 7 & $5 \cdot 3$ & 51 \\
\hline & 22 & $9 \cdot 7$ & 40 & 7 & $5 \cdot 7$ & I32 \\
\hline & 18 & $9 \cdot 2$ & 53 & 7 & $8 \cdot 2$ & 60 \\
\hline
\end{tabular}


intestinal lymph. No such rise was observed when arachis oil alone was given. Further, it is important to note that in no experiment did carotene appear in the lymph in detectable quantities.

\section{SUMMARY}

I. The oral administration of carotene to conscious rats with the intestinal lymphatic vessel cannulated resulted in a marked increase in the vitamin A content of the lymph, clearly indicating the conversion of carotene into vitamin $\mathrm{A}$ in either the intestine or intestinal wall.

2. No carotene was ever observed in the lymph during these experiments.

We are grateful to Prof. R. A. Gregory and Prof. R. A. Morton, F.R.S. for their advice and help. One of us (J. A.) participated in this work as the holder of the George Holt Fellowship in Physiology. British Insulated Callendar's Cables Ltd. kindly provided the specially prepared polythene tubing.

\section{REFERENCES}

Bollman, J. L., Cain, J. C., Grindlay, J. H. \& van Hook, E. (1948). F. Lab. clin. Med. 33, I349.

Bollman, J. L. \& van Hook, E. (1948). 7. Lab. clin. Med. 33, I348.

Coates, M. E., Thompson, S. Y. \& Kon, S. K. (1950). Biochem. F. 46, xxx.

Glover, J., Goodwin, T. W. \& Morton, R. A. (1947). Biochem. F. 41, xlv.

Glover, J., Goodwin, T. W. \& Morton, R. A. (1948). Biochem. F. 43, 5 I2.

Goodwin, T. W. \& Gregory, R. A. (r948). Biochem. 7. 43, 505.

Krause, R. F. \& Pierce, H. B. (1948). Arch. Biochem. 19, 145.

Lane, C. E. (1950). Science, Ixr, 47I.

Mann, J. D., Mann, F. D. \& Bollman, J. L. (1949). Amer. F. Physiol. 158, 3 I 1.

Mattson, F. H. (1948). F. biol. Chem. 176, 1467.

Mattson, F. H., Mehl, J. W. \& Deuel, H. J. Jr. (1947). Arch. Biochem. 15, 65.

Thompson, S. Y., Braude, R., Coates, M. E., Cowie, A. T., Ganguly, J. \& Kon, S. K. (1950). Brit. F. Nutrit. 4, 398.

Thompson, S. Y., Coates, M. E. \& Kon, S. K. (1950). Biochem. F. 46, xxx.

Thompson, S. Y., Ganguly, J. \& Kon, S. K. (1947). Brit. F. Nutrit. I, v.

Thompson, S. Y., Ganguly, J. \& Kon, S. K. (1949). Brit. F. Nutrit. 3, 50.

Wiese, C. E., Mehl, J. W. \& Deuel, H. J. Jr. (1947). Arch. Biochem. 15, 75. 